УДК 651.1: 347.77

DOI https://doi.org/10.11603/2312-0967.2019.1.9931

\title{
АКТУАЛЬНІСТЬ ВПРОВАДЖЕННЯ МЕХАНІЗМІВ ДЕРЖАВНО-ПРИВАТНОГО ПАРТНЕРСТВА ПРИ РЕАЛІЗАЦІЇ ІННОВАЦІЙНИХ ПРОЕКТІВ ЗІ СТВОРЕННЯ ЛІКАРСЬКИХ ЗАСОБІВ, ПРИЗНАЧЕНИХ ДЛЯ ЛІКУВАННЯ СОЦІАЛЬНО ЗАГРОЗЛИВИХ ЗАХВОРЮВАНЬ
}

\author{
О. В. Літвінова, О. В. Посилкіна \\ Національний фрармацевтичний університет, Харків \\ hlitvinova@gmail.com
}

\begin{abstract}
Мета роботи. Аналіз стану і тенденцій розвитку державно-приватного партнерства (ДПП) за кордоном при рішенні глобальних проблем при створенні інноваційних лікарських засобів (ЛЗ) для лікування соціально загрозливих захворювань, узагальнення світового досвіду щодо доцільності використання певних інструментів ДПП і розробка системи індикаторів для оцінювання результативності ДПП у фрармації.

Матеріали і методи. У процесі дослідження використано загальнонаукові методи пізнання, зокрема, системний підхід з використанням методів ретроспективного та системно-логічного аналізу, контент-аналіз.

Результати й обговорення. Визначені умови ефективної реалізації проектів ДПП, найбільш застосовані в різних країнах державні інструменти підтримки ДПП. Проаналізовані переваги і ризики застосування механізмів ДПП при реалізації інноваційних проектів, спрямованих на розробку лЗ, призначених для лікування соціально загрозливих захворювань. Запропоновано систему індикаторів оцінки результативності ДПП в фрармації за напрямами: співпраця, дослідна активність, практичні знання, людський капітал, фрінанси.

Висновки. Розвиток ДПП для активізації процесів створення інноваційних ЛЗ для лікування соціально загрозливих захворювань (гепатит, ВІЛ, онкопатології, антибіотикорезистентність, туберкульоз та ін.) сприяє об'єднанню унікальних інноваційних ресурсів та розподілу ризиків, пов'язаних із високим ступенем невизначеності результатів інноваційній діяльності; нарощуванню інноваційного потенціалу фрармацевтичної галузі в процесі спільної діяльності організацій; дозволяє розширити фрінансові ресурси, необхідні для ресрормування системи охорони здоров'я, сприяє оптимізації бюджетних витрат, підвищує есрективність інвестицій в охорону здоров'я, що в кінцевому підсумку сприяє підвищенню якості медичних і фрармацевтичних послуг.
\end{abstract}

Ключові слова: державно-приватне партнерство; інноваційний лікарський засіб; проект; соціально загрозливі захворювання.

Вступ. Зростаюча вартість, складність, ризикованість інноваційних проектів, вплив глобалізаційних процесів зумовлюють необхідність пошуку нових форм взаємодії, кооперації учасників науково-інноваційної сфрери. Фармацевтична галузь є особливою, зважаючи на глибину своєї залежності від наукомісткості й ефективності фундаментальних досліджень.

В останні десятиліття глобальні витрати фармацевтичних компаній (ФК) на інноваційні розробки лікарських засобів (ЛЗ) істотно зросли, а кінцева вартість оригінальних препаратів сьогодні часто $€$ дуже високою. В глобальному відношенні зростання галузі в останні десятиліття становило 4-7 \%, і сумарний обсяг фрармацевтичної продукції, яка щорічно реалізується, вже перевищив 1 трлн дол. Перераховані виклики ставлять нові завдання і проблеми щодо інноваційної політики, змушуючи найпотужніших учасників фрармацевтичної галузі і держави шукати нові механізми підтримки інноваційної діяльності [1].
В останні роки характерною тенденцією щодо розвитку інноваційної діяльності в багатьох країнах стало активне співробітництво держави і приватного бізнесу з метою підвищення ефективності управління, а також вирішення проблеми обмеженості бюджетного фрінансування. Подібний вид кооперації отримав назву «державно-приватне партнерство» (ДПП) - інституціональний й організаційний альянс між державою і бізнесом для реалізації суспільно значущих проектів і програм.

Різноманітність фрорм і моделей дПп зумовлена світовою практикою його застосування. Більшість зарубіжних країн вже давно усвідомила привабливість подібної форми кооперації між владою і бізнесом за умов реалізації великих інноваційних проектів і активно її використовують.

Так, зокрема в Індії завдяки активному використанню механізмів ДПП за період 2005-2015 рр. обсяг фрармринку збільшився з 6 до 30 млрд дол. В Республіці Казахстан за період 2008-2015 років реалізовано

ISSN 2312-0967. Pharmaceutical review. 2019. № 1 
Фармацевтичний менеджмент, маркетинг та логістика Pharmaceutical management, marketing and logistics

понад 20 проектів ДПП. Їх реалізація сприяла зростанню фрармринку Казахстану майже в 2,5 раза. Заслуговує уваги і досвід США у сорері розвитку ДПП в системі охорони здоров'я з метою прискорення розробки і допуску на ринок США препаратів для лікування хвороби Альцгеймера, цукрового діабету 2 типу, ревматоїдного артриту і системної червоної вовчанки [2].

3 точки зору Комісії ВООЗ з прав інтелектуальної власності, інновацій та громадської охорони здоров'я (Commission on intellectual property rights, innovation and public health), ДПП - ефективний спосіб вигідно використовувати можливості державного і приватного секторів для вирішення проблем охорони здоров'я, які подинці жодна із сторін належним чином вирішити не може [3].

Як свідчить міжнародний досвід, ДПП може реалізовуватися в різних сорерах: боротьба з поширеними/ хронічними захворюваннями; координація зусиль у cсрері R\&D та стимулювання розробки препаратів відповідно до потреб системи охорони здоров'я і структури захворюваності населення; створення інформаційної бази для прийняття регуляторних рішень; допомоги країнам 3 обмеженими ресурсами (міжнародне партнерство) і т. под. [3].

На сьогодні збереження і зміцнення здоров'я населення України є одним 3 пріоритетних напрямків діяльності держави у сфрері внутрішньої політики. Проблеми розробки та впровадження інноваційних л3 для лікування соціально загрозливих захворювань $€$ предметом вивчення багатьох вітчизняних і зарубіжних дослідників. Так, окремі теоретичні та практичні питання щодо організації та управління науково-дослідною й інноваційною діяльністю у фрармації розглядалися в роботах Б. П. Громовика, О. П. Гудзенка, Т. А. Грошового, І. А. Зупанця, А. А. Котвіцької, 3. М. Мнушко, А. С. Немченко, О. В. Посилкіної, О. П. Півень, М. М. Слободянюка, В. М. Толочка, В. П. Черниха та ін. $[4,5]$.

Водночас за кордоном досягнуто значних успіхів щодо використання механізмів ДПП в фрармації, які дозволяють розробляти інноваційні лЗ для лікування соціально загрозливих захворювань, в Україні застосування практики ДПП при реалізації інноваційних проектів в фрармації знаходиться на стадії становлення. Хоча слід зазначити, що в останні роки увага до цієї проблеми значно зросла.

Мета роботи. Аналіз стану і тенденцій розвитку ДПП за кордоном при рішенні глобальних проблем при створенні інноваційних ЛЗ для лікування соціально загрозливих захворювань, узагальнення світового досвіду щодо доцільності використання певних інструментів ДПП і розробка системи індикаторів для оцінювання результативності ДПП у фрармації.

Матеріали і методи. У процесі дослідження були використані загальнонаукові методи пізнання, зокрема, системний підхід з використанням методів ретро- спективного та системно-логічного аналізу, метод контент-аналізу.

Результати й обговорення. Як показали проведені дослідження, механізми ДПП реалізується в соціально значущих проектах світового масштабу за участю багатьох зацікавлених сторін (держави, срарміндустрії, науково-дослідних центрів, некомерційних громадських організацій і благодійних фрондів), що стимулює розробку інноваційних ЛЗ, які поодинці розробляти і виводити на ринок економічно невигідно, хоча потреба в них об'єктивно існує. Об'єднання ресурсів, розподіл фрінансового тягаря і ризиків роблять такі проекти більш привабливими і життєздатними.

Як свідчить зарубіжний досвід, охорона здоров'я і фрармація $є$ тими сорерами, де ДПП знайшло достатньо широке розповсюдження (табл. 1).

У фрармації можна виділити різноманітні напрямки досліджень, які пов'язані з розробкою інноваційних Л3, що мають високу соціальну значущість. Це в основному високопрогресивні, наукомісткі і високовитратні технології, які характеризуються високими ризиками протягом всього життєвого циклу Л3, а також мають високу вартість. Так, однією з актуальних задач сучасної фармації та медицини залишається лікування гепатиту С. Захворюваність і смертність, які пов'язані з інфекцією вірусу гепатиту С (ВГС), у всьому світі продовжують зростати. Щорічно від ускладнень, пов'язаних з ВГС, включаючи цироз печінки і гепатоцелюлярну карциному, вмирає приблизно 700000 чоловік.

3 метою підвищення ефективності та безпеки лікування гепатиту C інноваційними антивірусними препаратами прямої дії в США використовується механізм ДПП. Управління з контролю за продуктами і лікарськими засобами США (FDA) прагне забезпечити своєчасний доступ пацієнтів до нових методів лікування. Сучасний підхід полягає в тому, щоб вимагати від спонсорів препаратів проводити постмаркетингові дослідження (клінічні випробування IV фрази) для розширення знань та розуміння нових методів лікування. Однак іноді результати цих постмаркетингових досліджень і випробувань можуть запізнюватися і втрачати свою актуальність. Використання реальних свідчень для підвищення безпеки та ефективності нових ЛЗ може бути досягнуто завдяки надійному партнерству між державним і приватним секторами. Цей підхід був використаний Центром 3 оцінки та дослідження лікарських засобів, відділом противірусних продуктів у партнерстві з терапевтичною реєстраційною та дослідницькою мережею гепатиту C (HCV-TARGET). HCV-TARGET - кооперативний академічний консорціумом, який частково підтримується в рамках програми «Clinical and translational science award» та доповнюється суттєвою підтримкою з боку фармацевтичних спонсорів. Організація, яка очолювана Координаційним комітетом експертів

ISSN 2312-0967. Фармацевтичний часопис. 2019. № 1 
Фармацевтичний менеджмент, маркетинг та логістика Pharmaceutical management, marketing and logistics

Таблиця 1. Аналіз ссрер найбільшого розповсюдження проектів ДПП у країнах світу

\begin{tabular}{|c|c|c|c|c|c|c|c|c|c|c|}
\hline \multirow[b]{2}{*}{ Країна } & \multicolumn{10}{|c|}{ Об'єкти } \\
\hline & $\begin{array}{c}\text { авто- } \\
\text { дороги }\end{array}$ & $\begin{array}{c}\text { заліз- } \\
\text { ничні } \\
\text { лінії }\end{array}$ & $\begin{array}{c}\text { водопровід і } \\
\text { каналізація. } \\
\text { Житлове } \\
\text { будівництво }\end{array}$ & $\begin{array}{c}\text { переробка } \\
\text { і утилізація } \\
\text { відходів }\end{array}$ & $\begin{array}{l}\text { енер- } \\
\text { гетика }\end{array}$ & $\begin{array}{c}\text { охорона } \\
\text { здоров'я, } \\
\text { фрармація }\end{array}$ & освіта & $\begin{array}{c}\text { пеніте- } \\
\text { ціарний } \\
\text { заклад }\end{array}$ & $\begin{array}{l}\text { обо- } \\
\text { рона }\end{array}$ & oоpicn \\
\hline Австралія & $y$ & $y$ & $y$ & - & - & $y$ & $\mathrm{O}$ & $y$ & $y$ & - \\
\hline Бельгія & $y$ & $\mathrm{O}$ & $y$ & $y$ & - & $y$ & $\mathrm{O}$ & - & - & - \\
\hline Канада & $y$ & $y$ & $y$ & $y$ & - & $\mathrm{O}$ & $\mathrm{O}$ & $y$ & $\mathrm{O}$ & $y$ \\
\hline Фінляндія & $y$ & $\mathrm{O}$ & - & - & - & $y$ & $\mathrm{O}$ & - & - & $y$ \\
\hline Франція & $y$ & - & $y$ & - & - & - & - & - & $\mathrm{O}$ & - \\
\hline Німеччина & $y$ & $\mathrm{O}$ & $y$ & $\mathrm{O}$ & - & - & - & - & $\mathrm{O}$ & - \\
\hline Греція & $y$ & $y$ & - & - & - & 0 & $\mathrm{O}$ & - & - & - \\
\hline Голландія & y & $\mathrm{O}$ & $\mathrm{O}$ & - & - & - & - & - & - & - \\
\hline Ірландія & $y$ & O & $y$ & O & $y$ & - & O & $y$ & - & $y$ \\
\hline Італія & $\mathrm{O}$ & $y$ & 0 & $y$ & - & - & - & - & - & - \\
\hline Португалія & $y$ & 0 & $y$ & - & - & 0 & - & - & 0 & - \\
\hline Іспанія & $y$ & $y$ & $y$ & - & - & $y$ & - & - & - & - \\
\hline Великобританія & $\mathrm{y}$ & $y$ & $\mathrm{y}$ & $y$ & - & $y$ & $\mathrm{y}$ & $\mathrm{y}$ & $\mathrm{y}$ & $\mathrm{y}$ \\
\hline Південна Асррика & - & - & $\mathrm{y}$ & - & - & $\mathrm{O}$ & $\mathrm{O}$ & $\mathrm{y}$ & - & - \\
\hline США & $y$ & - & $y$ & - & - & - & - & - & - & - \\
\hline
\end{tabular}

Примітка. О - проекти оголошені, У - укладені угоди.

3 гепатології, включає Клінічний координаційний центр (базується в Університеті Флориди), і Координаційний центр даних (базується в Університеті Північної Кароліни). Діяльність цієї організації спрямована на фрормування ключових партнерських відносин між академічними центрами, громадськими об'єктами та приватною промисловістю. Керівний комітет забезпечує контроль і керівництво HCV-TARGET. Консультативна рада 3 питань промисловості HCV-TARGET, що складається з одного представника від кожного спонсора галузі, виконує функції консультативного органу, який надає консультативну допомогу та інформацію щодо використання мережевих даних та нових ініціатив в лікуванні гепатиту C. Консультативна рада FDA консультує мережу HCV-TARGET. HCV-TARGET $€$ важливим компонентом в інформуванні постмаркетингової безпеки нових способів лікування вірусного гепатиту C [6].

Також однією 3 найбільш актуальних соціальних і економічних проблем суспільства сьогодні $€$ ВІЛінорекція. Застосування антиретровірусної терапії ВІЛ-інфекції сприяло помітному скороченню захворюваності і смертності, зумовленої СНІДом. ВІЛінфекція перейшла з абсолютно фатального захворювання в терапевтично контрольоване. Значною мірою цьому сприяло активне застосування практики ДПП.

Зокрема, з метою підвищення ранньої діагностики новонароджених і тестування вірусного навантажен- ня пацієнтів на антиретровірусну терапію в Африці впроваджено 6 спільних проектів ДПП [7].

Актуальною соціальною проблемою у світі сьогодні $€$ розширення онкопатології. Статистика свідчить, що за останні 100 років за рівнєм захворюваності і смертності в світі онкопатологія перемістилася 3 десятого місця на друге, поступаючись лише хворобам серцево-судинної системи. За даними ВОО3, щороку кількість онкохворих збільшується на 10 млн чоловік. За прогнозами ВОО3, смертність від раку до 2030 року зросте на $45 \%$ порівняно 3 2007 роком.

Практика ДПП щодо лікування онкопатологій широко впроваджується за кордоном. Так, у рамках інституту здоров'я США впроваджено механізми ДПП для аналізу клінічно анотованих даних щодо біомаркерів онкопатологій. Колекція клінічних досліджень відповідала наступним критеріям включення: завершені рандомізовані дослідження за участю понад 300 пацієнтів (недрібноклітинний рак легенів, колоректальний рак, нирково-клітинний рак та меланома). Середня тривалість контракту з п'ятьма спонсорами становила 12 місяців. Було зібрано десять випробувань у 7085 пацієнтів, які охоплювали 12 схем лікування у 20 клінічних дослідженнях. Обмін та аналіз даних за умов проведення великих рандомізованих досліджень - широкий і багаторазовий, але значною мірою це - невикористаний ресурс для подальших досліджень [8].

ISSN 2312-0967. Pharmaceutical review. 2019. № 1 
Фармацевтичний менеджмент, маркетинг та логістика Pharmaceutical management, marketing and logistics

До 2000 р. середня загальна виживаність серед більшості пацієнтів з множинною мієломою, яка характеризується зростанням трансформованих плазматичних клітин, становила 3,5 року. У зв'язку із вказаним, у США створений Консорціум 3 дослідження множинної мієломи (Multiple myeloma research consortium, MMRC), який включає промисловість, FDA, а також фонд Myeloma research foundation (MMRF). Результатом його діяльності стало схвалення вже 9 нових препаратів, а також одержання нових даних щодо біологічних особливостей і складності геному, які пов'язані з множинною мієломою [9].

Нові ініціативи щодо співпраці між фрармацевтичними та біотехнологічними компаніями та Національним інститутом раку ( $\mathrm{NCl})$, Національним інститутом охорони здоров'я також спрямовані на впровадження препаратів для лікування онкопатологій. В програму включено 15 схвалених і досліджуваних лз шести фрармацевтичних компаній, включно Bristol-Myers Squibb, Eli Lilly and Company i Genentech [10].

Не менш актуальною соціальною проблемою, яка потребує інтеграції зусиль фрармацевтичної науки, бізнесу і держави, є туберкульоз. Туберкульоз із множинною лікарською стійкістю, як і раніше, являє кризу у сорері суспільної охорони здоров'я. За оцінками ВОО3, за останні роки засріксовано 558000 нових випадків туберкульозу зі стійкістю до рифрампіцину найефективнішого препарату першої лінії.

32003 р. Фонд Lilly підтримує некомерційне партнерство Lilly MDR-TB, яке охоплює понад 45 місцевих, національних, глобальних та неурядових організацій та урядів. Метою партнерства Lilly MDR-TB $€$ досягнення значного глобального впливу на мультирезистентний туберкульоз (MDR-TB) шляхом вирішення низки важливих потреб місцевої охорони здоров'я в країнах, які зазнали значного ураження: Китаї, Індії, Росії та Південній Африці. Результати досліджень аналізують та повідомляють урядам, експертам з питань медичної політики, місцевим і національним зацікавленим сторонам, у тому числі в інших країнах, що стикаються 3 подібними викликами MDR-TB [11].

ще однією актуальною глобальною соціально важливою проблемою, яка потребує інтеграції зусиль держави, науки, приватного бізнесу, є стійкість до антибіотиків. Численні урядові та недержавні установи закликають до розвитку ДПП і впровадження інноваційних механізмів фрінансування для вирішення цієї проблеми. Щоб реагувати на цю кризу в галузі охорони здоров'я, спільна програма Ініціативи 3 інноваційних ЛЗ інвестувала понад 660 млн євро, 3 метою узгодження внесків Європейської комісії та Європейської фредерації фрармацевтичних галузей та асоціацій у розробку нових антибактеріальних стратегій. Нова програма «The new drugs for bad bugs» (ND4BB), ініціатива «Інноваційні лікарські засоби», має кінцеву мету - посилити боротьбу з резистентністю до анти- біотиків на кожному рівні - від фрндаментальної науки та відкриття Л3, до клінічного розвитку та впровадження нових бізнес-моделей та відповідального використання антибіотиків. Для досягнення цієї мети в рамках програми ND4BB було започатковано сім проектів. Чотири 3 них включатимуть клінічні випробування нових протиінфекційних сполук, а також епідеміологічні дослідження. ND4BB надає платорорму, за допомогою якої зобов'язання та ресурси, необхідні всім сторонам, втілюються у спільну ініціативу ДПП [12].

Отже, як свідчать наведені приклади, співпраця між державою і приватними партнерами, яка орієнтована на досягнення спільної мети, допомогла подолати існуючі фрінансові та інші бар'єри і сприяла значним успіхам у кожній сфрері співпраці. Співпраця різних фрондів, академічних центрів, наукових установ, промисловості, спрямована в першу чергу на поліпшення результатів для пацієнтів. У кожному з наведених випадків жодне 3 досягнень не могло би відбутися своєчасно, якщо б партнери працювали самостійно, оскільки механізм ДПП створює умови для синергії зусиль багатьох партнерів для прискорення прогресу.

Проведені дослідження щодо узагальнення досвіду різних країн [13] дозволили визначити умови ефрективної реалізації проектів ДПП:

> довготривалість відносин між органами державної влади, місцевого самоврядування і приватними партнерами;

> збереження державної та комунальної фрорми власності на об'єкти 3 одночасним упровадженням механізмів управління інфраструктурою приватними партнерами;

> відкритість і прозорість діяльності органів державної та місцевої влади щодо визначення приватних партнерів;

$>$ забезпечення надання якісних і здешевлених послуг як показник результативності й ефективності ДПП;

> поєднання ресурсів фрінансово-кредитних установ під гарантії органів державної та місцевої влади;

$>$ розподіл ризиків, визначення зобов'язань та відповідальності в договорі ДПП;

$>$ захист інтересів та задоволення потреб громади, контроль за якістю надання послуг приватними партнерами, обговорення та моніторинг проектів за участю громадських організацій.

Також досліджено, що найбільше розповсюдження за кордоном отримали державні інструменти підтримки ДПП, наведені в таблиці 2.

Законодавчі засади ДПП в Україні з 2010 року регулюють Законом України «Про державно-приватне партнерство» (від 1 липня 2010 р. № 2404-VI 3 останніми змінами та доповненнями від 16.10.2012 р.), базові положення якого, за оцінками експертів, відповідають сучасним європейським

ISSN 2312-0967. Фармацевтичний часопис. 2019. № 1 
Фармацевтичний менеджмент, маркетинг та логістика Pharmaceutical management, marketing and logistics

Таблиця 2. Оцінка активності використання державних інструментів підтримки ДПП за кордоном

\begin{tabular}{|l|c|}
\hline \multicolumn{1}{|c|}{ Форми підтримки } & Активність використання \\
\hline Програмні державні інвестиції & +++ \\
\hline Податкові та митні пільги інвесторам & +++ \\
\hline Концесійні угоди & ++ \\
\hline Особливі економічні зони & ++ \\
\hline Державні інвестиційні фронди для реалізації великих інсраструктурних проектів & ++ \\
\hline Державні венчурні інвестиції & + \\
\hline Система заходів та інститутів з підтримки експорту & + \\
\hline Створеня спеціального координаційного органу з ДПп & + \\
\hline Створення Національного агентства по залученню інвестицій & ++ \\
\hline Банки розвитку & +++ \\
\hline Галузеві держкорпорації & +++ \\
\hline Інноваційні кластери & +++ \\
\hline Урядові контракти & +++ \\
\hline Розвиток науково-дослідної інфрраструктури & + \\
\hline
\end{tabular}

Примітки: +++ - висока активність використання, ++ - помірна активність використання; + - невисока активність використання.

правовим орієнтирам. Закон визначає, що проекти ДПП повинні відповідати таким основним критеріям: мати довготривалий характер (понад 5 років); передбачати передання приватному партнеру частини ризиків у процесі реалізації проектів; мати вищі техніко-економічні показники есрективності, ніж у разі реалізації без участі приватного партнера. Водночас зазначений Закон має й певні недоліки. Поперше, не встановлено мінімальну частку участі у проекті приватного партнера (зокрема, у розвинених країнах мінімальна частка приватного фінансування складає 25 \%). У зв'язку з цим навіть мінімальна частка приватного фрінансування у спільному проекті дозволяє відносити його до категорії ДПП, перекладаючи більшу частину відповідальності на державу. По-друге, відсутні чітко визначені механізми практичної реалізації (визначення етапів реалізації проектів ДПП, створення мотивації для іноземних інвесторів тощо). По-третє, відповідно до ст. 7 державно-приватне партнерство поширюється на об'єкти, що перебувають у державній або комунальній власності чи належать АР Крим; тим самим унеможливлюється реалізація таких проектів, як будівництво об'єктів приватним партнером 3 наступним їх передаванням державному (комунальному) партнеру. По-четверте, не визначена роль Державного фонду регіонального розвитку у фрінансуванні проектів ДПП [14].

За даними Міністерства економічного розвитку і торгівлі України станом на 1 липня 2018 р. укладено 192 договори ДПП, з яких реалізується 66, 126 договорів не реалізується (4 договори - закінчено термін дії, 9 договорів - розірвано, 113 договорів - не виконується). У галузі охорони здоров'я реалізується один договір, що становить 1,5 \% від загальної кількості. Таким чином, як показав проведений аналіз, в Україні, на відміну від зарубіжних країн, механізми ДПП в орармації не використовуються. Наразі фрахівці МОЗ України розробили методичні рекомендації для державних та комунальних закладів охорони здоров'я, для працівників органів управління у сорері охорони здоров'я для впровадження проектів державно-приватного партнерства у сорері охорони здоров'я [15], які допоможуть залучати інвестиції у модернізацію медзакладів, але вказане не стосується фрармацевтичної розробки Лз.

Безумовно, реалізація механізмів ДПП у фармації і охороні здоров'я створює певні переваги як для держави, фрірм-розробників і виробників Л3, так і для пацієнтів. Але подібні проекти характеризуються і потенційними ризиками. Результати узагальнення переваг і ризиків щодо ДПП при створенні ЛЗ, призначених для лікування соціально загрозливих захворювань, наведені в таблиці 3.

3 метою оцінки результативності проектів ДПП у фрармації ми систематизували та вдосконалили групи показників, запропонували систему відповідних індикаторів (рис. 1).

Отже, розвиток ДПП в системі охорони здоров'я і в фрармації в Україні дуже актуальна тема. Застосування цього механізму може бути доцільним з точки зору модернізації системи охорони здоров'я, поліпшення якості надання медичних послуг та підвищення доступності до ефективних і безпечних ліків. Важливу роль у розвиткук ДПП може також відігравати з точки зору підвищення інвестиційної привабливості вітчизняної фрармгалузі для зарубіжних інвесторів і міжнародних організацій.

ISSN 2312-0967. Pharmaceutical review. 2019. № 1 
Фармацевтичний менеджмент, маркетинг та логістика

Pharmaceutical management, marketing and logistics

Таблиця 3. Характеристики переваг і ризиків застосування механізмів ДПП при створенні інноваційних Л3, призначених для лікування соціально загрозливих захворювань

\begin{tabular}{|c|c|}
\hline Переваги & Ризики \\
\hline $\begin{array}{l}\text { 1. Довгострокова перспектива і зниження навантаження на державний } \\
\text { бюджет при фрінансуванні системи охорони здоров'я } \\
\text { 2. Оптимальний розподіл ризиків проектів при створенні інноваційних } \\
\text { лз між державою і приватним партнером, кожна зі сторін приймає на } \\
\text { себе тільки ті ризики, якими вона може керувати найбільш ефрективно } \\
\text { 3. Можливість реалізації значної кількості різних проектів і впрова- } \\
\text { дження інноваційних рішень і досвіду приватних інвесторів у фрармації } \\
\text { 4. Конкурсний порядок укладення угод дПп забезпечує підбір най- } \\
\text { більш кваліфрікованих представників бізнесу для реалізації інновацій- } \\
\text { них проектів } \\
\text { 5. Взаємовигідна співпраця як фрактор стимулювання фрармацевтичних } \\
\text { компаній } \\
\text { 6. Скорочення термінів реалізації інноваційних проектів щодо розроб- } \\
\text { ки. виробництва і виведення на ринок нових лз }\end{array}$ & $\begin{array}{l}\text { 1. Складність структурування відносин } \\
\text { між учасниками проектів ДПП (деталь- } \\
\text { ний розгляд прав і обов'язків кожної зі } \\
\text { сторін) } \\
\text { 2. Складність корекції угоди при не- } \\
\text { сприятливих змінах зовнішніх умов, } 3 \\
\text { огляду на масштабність проектів дПП, } \\
\text { їх капіталомісткості і довгостроковості } \\
\text { реалізації } \\
\text { 3. Загроза нейтралізації фрінансової ви- } \\
\text { годи від залучення приватного капіталу, } \\
\text { через тривалі і витратні процедури про- } \\
\text { ведення інвестиційних конкурсів }\end{array}$ \\
\hline
\end{tabular}
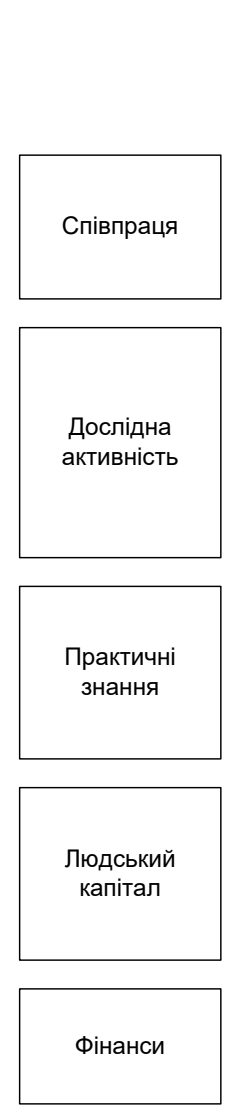
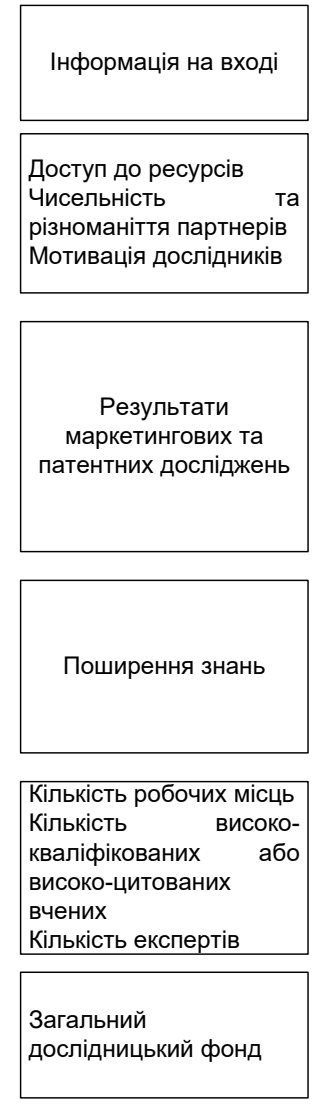
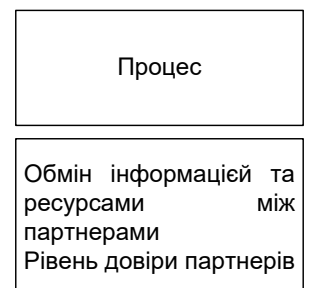

Рівень довіри партнерів
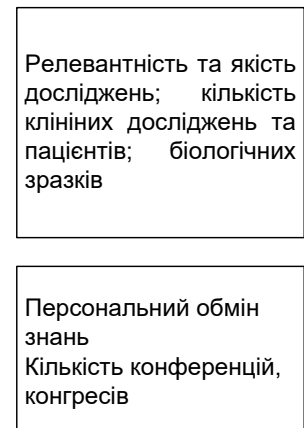

конгресів

\begin{tabular}{|lr|}
\hline Відсоток & дослідників, \\
які брали & участь в в \\
тренінгах & державно- \\
приватного & \\
партнерства \\
Tренінги та навчання \\
\hline
\end{tabular}

Кошти для дослідників Кошти для захисту об'єктів інтелектуальної власності

\section{Інформація на виході \\ Чисельність \\ завершених проектів \\ Чисельність статей 3 \\ інтернац. співпрацею \\ Індекс партнерства}

\section{Кількість аналізів,}

біомаркерів, баз даних,

стандартів, методів

клінічних досліджень,

моделей на тваринах

in vitro; наукових

публікацій; нових

технологій

\section{Кількість презентацій}

на конференціях

Руководства

рекомендації

найкращих практик

Доповіді досліджень

\section{Дослідницькі гранти}

Позиції $\mathrm{PhD}$

Навички персоналу

Програми розвитку

\section{Контрольні точки}

(основні параметри)

проектів; кількість та

якість патентів

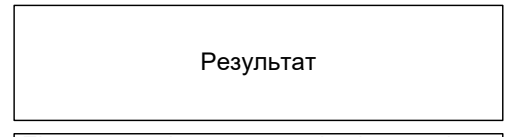

Підвищення ділової репутації й інвестиційної привабливості фармацевтичних компаній для зарубіжних партнерів; підвищення рентабельності інноваційної діяльності, зниження ризиків і тривалості інноваційних проектів

Зростання кількості ЛЗ, створених в рамках проектів ДПП, кількість і вартість інноваційних проектів, покращення науково-дослідної матеріальної бази

\begin{tabular}{|l} 
Збільшення активності \\
вітчизняних науковців \\
Збільшення цитування \\
публікаціях,
\end{tabular}

\section{Перспективи кар'єрного зростання}

Підвищення відсотку дослідників в фармації

Підвищення зростання наукового потенціалу в галузі

Об'єднання фінансових ресурсів для реалізації крупних дослідницьких проектів Створення нових венчурних компаній, стартапів

Рис. 1. Запропонована система індикаторів оцінювання результативності проектів державно-приватного партнерства у фрармації.

Висновки. Досліджено, що розвиток ДПП для активізації процесів створення інноваційних ЛЗ для лікування соціально загрозливих захворювань (гепатит, ВІЛ, онкопатології, антибіотикорезистентність, туберкульоз та ін.) сприяє об'єднанню унікальних інноваційних ресурсів та розподілу ризиків, пов'язаних із високим ступенем невизначеності результатів інноваційній діяльності; нарощуванню інноваційного по- тенціалу фрармацевтичної галузі; дозволяє розширити орінансові ресурси, необхідні для ресрормування системи охорони здоров'я та активізації науково-дослідної й інноваційної діяльності в фрармації, оптимізує бюджетні витрати, підвищує ефективність інвестицій в охорону здоров'я, що в кінцевому підсумку сприяє підвищенню якості медичних і фрармацевтичних послуг.

ISSN 2312-0967. Фармацевтичний часопис. 2019. № 1 
Фармацевтичний менеджмент, маркетинг та логістика

Pharmaceutical management, marketing and logistics

Визначені умови ефективної реалізації проектів ДПП, найбільш застосовувані в різних країнах, державні інструменти підтримки ДПП. Проаналізовані переваги і ризики застосування механізмів дПп при реалізації інноваційних проектів, спрямованих на розробку лз, призначених для лікування соціально загрозливих захворювань.

Запропоновано систему індикаторів оцінки результативності ДПП в фрармації за напрямами: співпраця, дослідна активність, практичні знання, людський капітал, фрінанси.

Конфлікт інтересів: відсутній.

Conflicts of interest: author has no conflict of interest to declare.

\title{
АКТУАЛЬНОСТЬ ВНЕДРЕНИЯ МЕХАНИЗМОВ ГОСУДАРСТВЕННО-ЧАСТНОГО ПАРТНЕРСТВА ПРИ РЕАЛИЗАЦИИ ИННОВАЦИОННЫХ ПРОЕКТОВ ПО СОЗДАНИЮ ЛЕКАРСТВЕННЫХ СРЕДСТВ, ПРЕДНАЗНАЧЕННЫХ ДЛЯ ЛЕЧЕНИЯ СОЦИАЛЬНО ОПАСНЫХ ЗАБОЛЕВАНИЙ
}

\author{
Е. В. Литвинова, О. В. Посылкина \\ Национальный фрармацевтический университет, Харьков \\ hlitvinova@gmail.com
}

Цель работы. Анализ состояния и тенденций развития государственно-частного партнерства (ГЧП) за рубежом при решении глобальных проблем при создании инновационных лекарственных средств (ЛС) для лечения социально опасных заболеваний, обобщение мирового опыта целесообразности использования определенных инструментов ГЧП и разработка системы индикаторов для оценки результативности ГЧП в фрармации.

Материалы и методы. В процессе исследования были использованы общенаучные методы познания, в частности, системный подход с использованием методов ретроспективного и системно-логического анализа, контент-анализ. Результаты и обсуждение. Определены условия эффрективной реализации проектов ГЧП, наиболее используемые в различных странах государственные инструменты поддержки ГЧП. Проанализированы преимущества и риски применения механизмов ГЧП при реализации инновационных проектов, направленных на разработку лС, предназначенных для лечения социально опасных заболеваний. Предложена система индикаторов оценки результативности ГЧП в фрармации по направлениям: сотрудничество, исследовательская активность, практические знания, человеческий капитал, фринансы.

Выводы. Развитие ГЧП для активизации процессов создания инновационных лС для лечения социально опасных заболеваний (гепатит, ВИЧ, онкопатологии, антибиотикорезистентность, туберкулез и др.) способствует объединению уникальных инновационных ресурсов и распределению рисков, связанных с высокой степенью неопределенности результатов инновационной деятельности; наращиванию инновационного потенциала фрармацевтической отрасли в процессе совместной деятельности организаций; позволяет расширить фринансовые ресурсы, необходимые для реформирования системы здравоохранения, оптимизирует бюджетные расходы, повышает эфффективность инвестиций в здравоохранение, что в конечном итоге способствует повышению качества медицинских и фармацевтических услуг.

Ключевые слова: государственно-частное партнерство; инновационный препарат; проект; социально опасные заболевания.

\section{PUBLIC-PRIVATE PARTNERSHIP IN THE IMPLEMENTATION OF INNOVATIVE PROJECTS ASSOCIATED WITH PHARMACEUTICAL DEVELOPMENTS FOR THE TREATMENT OF SOCIALLY SIGNIFICANT DISEASES}

\section{O. V. Litvinova, O. V. Posilkina}

\author{
National University of Pharmacy, Kharkiv \\ hlitvinova@gmail.com
}

The aim of the work. Analysis of the state and development trends of public-private partnerships (PPP) abroad in solving global problems in creating innovative drugs for the treatment of socially significant diseases, generalizing world experience of the feasibility of using certain PPP tools and developing the system of indicators to assess the effectiveness of PPP in pharmacy.

Materials and Methods. In the process of research we used general scientific methods of cognition, in particular, a systematic approach using methods of retrospective and system-logical analysis, content analysis.

ISSN 2312-0967. Pharmaceutical review. 2019. № 1 
Results and Discussion. The conditions for the effective implementation of PPP projects, the most commonly used stateowned tools for PPP support in various countries, were determined. The benefits and risks of using PPP mechanisms in the implementation of innovative projects is associated with pharmaceutical developments for the treatment of socially significant diseases were analyzed. The system of indicators for evaluating the effectiveness of PPP in pharmacy in the following areas: cooperation, research activity, know-how, human capital, finance, was proposed.

Conclusions. The development of PPP to enhance the creation of innovative drugs for the treatment of socially significant diseases (hepatitis, HIV, oncopathology, antibiotic resistance, tuberculosis, etc.) contributes to the unification of unique innovative resources and the distribution of risks associated with a high degree of uncertainty of innovative activity results; increasing the innovative potential of the pharmaceutical industry in the process of joint activity organizations; allows to expand financial resources needed to reform the health care system, optimizes budget expenditures, increases the efficiency of investments in health care, which ultimately contributes to improving the quality of medical and pharmaceutical services.

Key words: public-private partnership; innovative drug; project; socially significant diseases.

\section{Список літератури}

1. Мамедьяров 3. А. Инструменты государственной инновационной политики в фармацевтической отрасли США и ЕС / 3. А. Мамедьяров // МИР (Модернизация. Инновации. Развитие). - 2017. - № 1. - C. 105-114. DOI: https://doi.org/10.18184/2079-4665.2017.8.1.105-114.

2. Варнавский В. Г. Государственно-частное партнерство в здравоохранении: международный опыт / В. Г. Варнавский // Управление здравоохранением. - 2010. № 1. - С. 9-16.

3. Дмитрик Е. Государственно-частное партнерство сорере здравоохранения. Международный опыт / Е. Дмитрик // Еженедельник Аптека. - 2017. - № 1104 (33). - [Электронный ресурс]. - Режим доступа : https:// www.apteka.ua/article/423444.

4. Котвіцька А. А. Дослідження нормативно-правового регулювання імпортозамінного виробництва лікарських засобів в Україні / А. А. Котвіцька, В. Г. Костюк // Управління, економіка та забезпечення якості В фрармації. - 2016. - № 1. - С. 44-48.

5. Фармація XXI століття: тенденції та перспективи : матеріали VIII з'їзду фрармацевтів України : у 2-х т., м. Харків, 13-16 вересня 2016 р. - Харків : НФаУ, 2016. - T. $1 .-458$ c.

6. Public-private partnership: targeting real-world data for hepatitis c direct-acting antivirals / P. Mishra, J. Florian, J. Peter [et al.] // Gastroenterology. - 2017. - Vol. 153, No 3. - P. 626-631. DOI: 10.1053/j.gastro.2017.07.025.

7. Role of public-private partnerships in achieving UNAIDS HIV treatment targets / R. Shrivastava, P. Fonjungo, Y. Kebede [et al.] // BMC Health Serv. Res. - 2019. Vol. 19, No 1. - P. 1-10. DOI: 10.1186/s12913-018-3744-z. 8. Vol-PACT: a foundation for the NIH public-private partnership that supports sharing of clinical trial data for the development of improved imaging biomarkers in oncology / L. Dercle, D. Connors, Y. Tang [et al.] // JCO Clin. Cancer Inform. - 2018. - No 2. - P. 1-12. DOI: 10.1200/ CCI.17.00137.

\section{Referens}

1. Mamedyarov ZA. Public innovation policy in the pharmaceutical industry: the cases of the EU and USA. MIR (Modernizatsiya. Innovatsiya. Razvitiye). 2017;8(1): 105-114.
9. Ramsey B. W. Academic, foundation, and industry collaboration in finding new therapies / B. W. Ramsey, G. T. Nepom, S. Lonial // N. Engl. J. Med. - 2017. - Vol. 376, No 18. - P. 1762-1769. DOI: 10.1056/NEJMra1612575.

10. Abbasi J. Public-private partnership speeds investigator access to cancer drugs / J. Abbasi // JAMA. - 2017. - Vol. 317, No 8. - P. 797. DOI: 10.1001/jama.2017.1089. 11. Shelby P. W. Collaborative public-private initiatives targeting multidrug-resistant tuberculosis (MDR-TB) supported by the Lilly MDR-TB Partnership: experiences in 20122016 / P. Shelby, M. Lia, A. Israel // J. Healthc Leadersh. - 2017. - No 9. - P. 47-57. DOI: 10.2147/JHL.S130207.

12. The innovative medicines initiative's new drugs for bad bugs programme: European public-private partnerships for the development of new strategies to tackle antibiotic resistance / T. Kostyanev, M. Bonten, S. O'Brien [et al.] // J. Antimicrob. Chemother. - 2016. - Vol. 71, No. 2. - P. 290-295. DOI: $10.1093 / \mathrm{jac} / \mathrm{dkv} 339$.

13. Устінова Е. О. Державно-приватне партнерство: досвід країн Європейського Союзу / Е. О. Устінова // Матеріали науково-практичної конференції «Державне управління та місцеве самоврядування: історія та сучасність», Харків, 2012. - С. 14-16.

14. Баталов О. А. Особливості застосування державноприватного партнерства як механізму реалізації нової регіональної політики. Аналітична записка / О. А. Баталов, І. В. Валюшко. - [Електронний ресурс]. - Режим доступу : http://www.niss.gov.ua/articles/1239/.

15. Методичні рекомендації для державних та комунальних закладів охорони здоров'я, для працівників органів управління у ссрері охорони здоров'я для впровадження проектів державно-приватного партнерства у сорері охорони здоров'я / Р. Ілик, І. Литовченко, М. Слобоніченко [та ін.]. - Київ, 2018. - [Електронний ресурс]. - Режим доступу : http://moz.gov.ua/uploads/1/7840-1234567890.pdf.

DOI: $\quad$ https://doi.org/10.18184/2079-4665.2017.8.1.105114. Russian.

2. Varnavsky VG. Public-private partnership in healthcare:

ISSN 2312-0967. Фармацевтичний часопис. 2019. № 1 
international experience. Uprav zdravookr. 2010;1: 9-16. Russian.

3. Dmitrik E. Public-private partnership in healthcare. International experience. Yezened apteka. 2017;1104(33). Available from: https://www.apteka.ua/article/423444. Russian.

4. Kotvitska AA, Kostiuk VH. Investigation of normative legal regulation of import-substituting production of medicines in Ukraine. Upravl, ekonomika ta zapezp yakosti v farmatsii. 2016;1:44-8. DOI: https://doi.org/10.24959/ uekj.16.6. Ukrainian.

5. Pharmacy of the 21st century: Trends and prospects: Materials of VIII Congress of Pharmacists of Ukraine. Kharkiv: NFaU; 2016. Ukrainian

6. Mishra P, Florian J, Peter J, Vainorius M, Fried MW, Nelson DR, Birnkrant D. Public-private partnership: targeting real-world data for hepatitis c direct-acting antivirals. Gastroenterology. 2017; 153(3): 626-31. DOI: 10.1053/j.gastro.2017.07.025.

7. Shrivastava R, Fonjungo PN, Kebede Y, Bhimaraj R, Zavahir S, Mwangi C, Gadde R [et al.]. Role of public-private partnerships in achieving UNAIDS HIV treatment targets. BMC Health Serv Res. 2019;19(1): 46. DOI: 10.1186/ s12913-018-3744-z.

8. Dercle L, Connors DE, Tang Y, Adam SJ, Gönen M, Hilden P, Karovic $S$ et al. Vol-PACT: A Foundation for the $\mathrm{NIH}$ public-private partnership that supports sharing of clinical trial data for the development of improved imaging biomarkers in oncology. JCO Clin Cancer Inform. 2018;(2): 1-12. DOI: 10.1200/CCI.17.00137.

9. Ramsey BW, Nepom GT, Lonial S. Academic, foundation, and industry collaboration in finding new therapies. $\mathrm{N}$ Engl J Med. 2017;376(18): 1762-9. DOI: 10.1056/NEJMra1612575.
10. Abbasi J. Public-private partnership speeds investigator access to cancer Drugs. JAMA. 2017;317(8): 797. DOI: 10.1001/jama.2017.1089.

11. Shelby PW, Lia MP, Israel A. Collaborative public-private initiatives targeting multidrug-resistant tuberculosis (MDR-TB) supported by the Lilly MDR-TB Partnership: experiences in 2012-2016. J Healthc Leadersh. 2017;9:4 7-57. DOI: $10.2147 /$ JHL.S130207.

12. Kostyanev T, Bonten MJ, O'Brien S, Steel H, Ross S, François $B$, Tacconelli $E$, et al.The innovative medicines initiative's new drugs for bad bugs programme: European public-private partnerships for the development of new strategies to tackle antibiotic resistance. J Antimicrob Chemother. 2016;71(2): 290-5. DOI: 10.1093/jac/dkv339.

13. Ustinova EO. Public private partnership: experience of European Union countries. Materials of the scientific and practical conference "Public administration and local selfgovernment: history and modernity", Kharkiv; 2012. Ukrainian.

14. Batalov OA., Valyushko IV. Features of the use of public-private partnership as a mechanism for implementing a new regional policy. Analytical note. Available from: http:// www.niss.gov.ua/articles/1239/. Ukrainian.

15. Ilyk R, Litovchenko I, Slobonichenko M, Pitel L, Korchakov-Khib N. Methodical recommendations for state and municipal health care institutions, for employees of health care management agencies for implementation of publicprivate partnership projects in health care field. [Методичні рекомендації для державних та комунальних закладів охорони здоров'я, для працівників органів управління у сорері охорони здоров'я для впровадження проектів державно-приватного партнерства у ссрері охорони здоров'я] Kyiv; 2018. Available from: http://moz.gov.ua/uploads/1/7840-1234567890.pdf. Ukrainian.

Надійшла до редакції / Received: 07.02.2019 Після доопрацювання / Revised: 22.02.2019, 13.03.2019 Прийнято до друку / Accepted: 14.03.2019

\section{Відомості про авторів:}

Літвінова О.В. - д-р. фрармац. н., доц. каф. управління і економіки підприємства, Національний фрармацевтичний університет, Харків, Україна. E-mail: hlitvinova@gmail.com, ORCID 0000-0003-1578-7398

Посилкіна О.В. - д-р. фрармац. н., профр., зав. каф. управління і економіки підприємства, Національний срармацевтичний університет, Харків, Україна. E-mail: o.posilkina@gmail.com, ORCID 0000-0003-4529-4332

\section{Information about authors:}

Litvinova O.V. - DS (Pharmaceutical Sciences), Associate Professor of the Management and Economics of Enterprise Department, National University of Pharmacy, Kharkiv, Ukraine. E-mail: hlitvinova@gmail.com, ORCID 0000-0003-15787398

Posilkina O.V. - DS (Pharmaceutical Sciences), Professor, Head of the Management and Economics of Enterprise Department, National University of Pharmacy, Kharkiv, Ukraine. E-mail: o.posilkina@gmail.com, ORCID 0000-0003-4529-4332

ISSN 2312-0967. Pharmaceutical review. 2019. № 1 